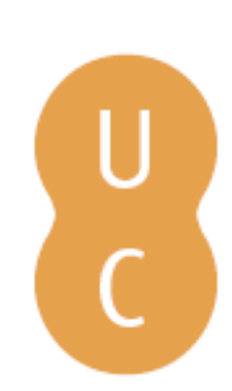

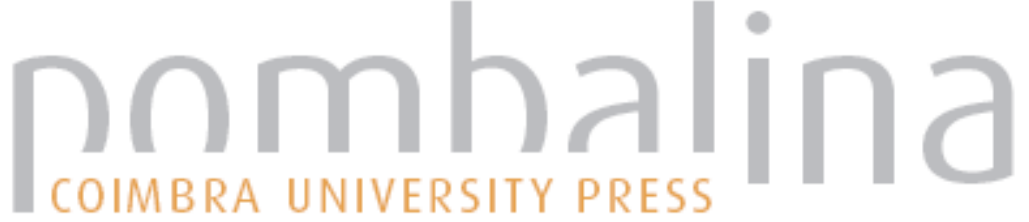

À mesa do rei : cultura alimentar e consumo no século $\mathrm{XVI}$

Autor(es): $\quad$ Buescu, Ana Isabel

Publicado por: Imprensa da Universidade de Coimbra

URL

persistente: URI:http://hdl.handle.net/10316.2/31577

DOI: $\quad$ DOI:http://dx.doi.org/10.14195/978-989-26-0201-1_1

Accessed : $\quad$ 26-Apr-2023 10:37:35

A navegação consulta e descarregamento dos títulos inseridos nas Bibliotecas Digitais UC Digitalis, UC Pombalina e UC Impactum, pressupõem a aceitação plena e sem reservas dos Termos e Condições de Uso destas Bibliotecas Digitais, disponíveis em https://digitalis.uc.pt/pt-pt/termos.

Conforme exposto nos referidos Termos e Condições de Uso, o descarregamento de títulos de acesso restrito requer uma licença válida de autorização devendo o utilizador aceder ao(s) documento(s) a partir de um endereço de IP da instituição detentora da supramencionada licença.

Ao utilizador é apenas permitido o descarregamento para uso pessoal, pelo que o emprego do(s) título(s) descarregado(s) para outro fim, designadamente comercial, carece de autorização do respetivo autor ou editor da obra.

Na medida em que todas as obras da UC Digitalis se encontram protegidas pelo Código do Direito de Autor e Direitos Conexos e demais legislação aplicável, toda a cópia, parcial ou total, deste documento, nos casos em que é legalmente admitida, deverá conter ou fazer-se acompanhar por este aviso. 
Isabel dos Guimarães Sá Máximo García Fernández (directores)

\section{PORTAS ADENTRO comer, vestir, habitar} (ss. XVI-XIX) 


\title{
À MESA DO REI. CULTURA ALIMENTAR E CONSUMO NO SÉCULO XVI
}

\author{
ANA IsABEL BuEsCU \\ Departamento de História. Faculdade de Ciências Sociais e Humanas \\ Universidade Nova de Lisboa
}

A Iria Gonçalves

O campo de investigação relativo à história da alimentação e da mesa é um campo de estudos complexo, que convoca não só a história e a cultura material, mas também a antropologia, a sociologia, a etnologia, a psicologia, a história de arte e a história das ideias, entre outras disciplinas, perfilando-se, hoje, como um domínio de relevo na historiografia. Contudo, nem sempre foi assim. Na verdade, um longo percurso foi feito desde o século XIX em que, rompendo de forma um pouco isolada e discreta a inquestionável supremacia da história política, a alimentação ia aflorando como possibilidade de investigação, sem contudo conseguir situar-se num horizonte histórico, sobretudo sob o ponto de vista de uma reflexão teórica e de uma definição de carácter metodológico. Como já foi observado no que diz respeito à historiografia francesa, a «vida material» e, nela, a problemática específica da alimentação, constituíam, então, sobretudo uma derivação, «decorativa» e amável, que empenhava uma erudição sem dúvida minuciosa, mas decisivamente menor.

Embora já antes tivessem surgido obras que dariam um contributo assinalável para a futura afirmação deste campo historiográfico, apenas nos anos sessenta do século XX os problemas relativos à alimentação assumiram plenamente um lugar no campo da reflexão e da investigação históricas ${ }^{1}$. Em

${ }^{1}$ André Burguière, «Alimentation», in Dictionnaire des Sciences Historiques, dir. André Burguière, Paris, PUF, 1986, pp. 7-11. 
França, na senda de avanços múltiplos quer da história económica quer da história social, bem como de um diálogo interdisciplinar fecundo com a etnologia e a antropologia ${ }^{2}$, a chamada nouvelle histoire teve um papel decisivo na afirmação deste novo território ${ }^{3}$, consagrado e amplificado sobretudo a partir da obra pioneira e em certo sentido fundadora de Jean-Louis Flandrin ${ }^{4}$, e, em Itália, de Massimo Montanari ${ }^{5}$, bem como dos resultados de um conjunto de importantes encontros científicos, que comprovavam e cimentavam, também, a rápida irradiação deste novo objecto historiográfico ${ }^{6}$. Resumidamente embora, assim se lançaram as bases para uma história da alimentação, ancorada na tripla e fundamental perspectiva da «produção», do «consumo» e do que podemos, genericamente, designar por «gosto», que tem de integrar-se, como observa Roland Barthes, no horizonte de um quadro teórico a que a complexidade do tema obriga: a história da alimentação não é, simplesmente, a história do que se come, uma colecção de produtos submetidos a uma apreciação estatística ou

${ }^{2}$ Onde tem lugar de indiscutível relevo a poderosa obra de Claude Lévi-Strauss, de que destacamos la trilogía Le Cru et le Cuit, Paris, 1964; Du Miel aux Cendres, Paris, 1966, L'Origine des Manières de Table, Paris, 1968.

${ }^{3}$ Ver Os Cahiers des Annales, 28, Pour une Histoire de l'Alimentation, ed. Jean-Jacques Hémardinquer, Paris, Armand Colin, 1970, precedido de uma Introdução Geral da autoria de Fernand Braudel, intitulada «Alimentation et catégories de l'histoire», pp. 15-19, publicada pela primeira vez na revista Annales, 16, 1961.

${ }^{4}$ Entre outros estudos de Jean-Louis Flandrin, «Le goût et la nécessité: sur l'usage des graisses alimentaires dans les cuisines d'Europe occidentale (XIVe-XVIIIe siècle)», Annales ESC, n. 3, 1983, pp. 369-401; «Internationalisme, nationalisme et régionalisme dans la cuisine des XIVe et XVe siècles», in Manger et Boire au Moyen Âge, Actes du Colloque de Nice (15-17 octobre 1982), Paris, Les Belles Lettres, 1984, pp. 75-91; Jean-Louis Flandrin, "A distinção pelo gosto», in História da Vida Privada, dir. Philippe Ariès e Georges Duby, vol. 3 - Do Renascimento ao Século das Luzes, dir. Roger Chartier, Porto, Edições Afrontamento, 1990, pp. 266-309 (ed. francesa 1986); Chronique de Platine. Pour une Gastronomie Historique, Paris, Éditions Odile Jacob, 1992; Jean-Louis Flandrin e Massimo Montanari (dir.), Histoire de l'Alimentation, Paris, Fayard, 1997 (ed. portuguesa, Terramar, 1998-2001). Desaparecido em 2001, o papel pioneiro de Flandrin neste domínio, e destacado noutros como a demografia ou a sexualidade, está presente no volume publicado em sua homenagem: Le Désir et le Goût. Une Autre Histoire (XIIIe-XVIIIe siècles), dir. Odile Redon, Line Sallmann e Sylvie Steinberg, Saint Denis, Presses Universitaires de Vincennes, 2005.

${ }^{5}$ Massimo Montanari, L'Alimentazione contadina nell'alto Medioevo, Napoli, Liguore, 1985; Alimentazione e cultura nel Medioevo, $2^{\mathrm{a}}$ ed., Roma, Laterza, 1992 (1 ${ }^{\mathrm{a}}$ ed. 1988); La fame e l'abbondanza. Storia dell'Alimentazione in Europa, Roma, Laterza, 1993.

${ }^{6}$ Como é o caso, entre outros, dos colóquios Pratiques et discours alimentaires à la Renaissance, Actes du Colloque de Tours, 1977, org. Jean-Claude Margolin e Robert Sauzet, Paris, Maisonneuve et Larose, 1982; Manger et Boire au Moyen Âge, Actes du Colloque de Nice (15-17 octobre 1982), Paris, Les Belles Lettres, 1984; La Sociabilité à Table. Commensalité et Convivialité à Travers les Ages; ou ainda de Alimentazione e Nutrizione secc.XIII-XVIII. Atti della «Ventottesima Settimana di Studi» do Istituto Internazionale di Storia Económica «F. Datini»Prato, 22-27 aprile 1996, dir. Simonetta Cavaciocchi, Florença, Le Monnier, 1997. 
dietética, mas, ao mesmo tempo, «[...] un système de communication, un corps d'images, un protocole d'usages, de situations et de conduites»?

No caso português, a história da alimentação nas épocas medieval e moderna, nas suas mais diversas perspectivas e afloramentos, conta com nomes que, alguns deles de forma pioneira e decisiva, lançaram entre nós, a partir de meados dos anos sessenta, este então novo objecto historiográfico. Sem pretendermos ser exaustivos num campo que também entre nós tem vindo a registar um incremento assinalável sob o ponto de vista historiográfico nos últimos anos ${ }^{8}$, impõe-se a referência a alguns desses nomes, com destaque para Oliveira Marques ${ }^{9}$, Salvador

${ }^{7}$ Roland Barthes, «Pour une psycho-sociologie de l'alimentation contemporaine», in Cahiers des Annales, 28, ob. cit., p. 309.

${ }^{8}$ Refiram-se, entre outros estudos publicados, restringindo-nos aos últimos 20 anos, os de Robim Amorim, Da Mão para a Boca. Para uma História da Alimentação em Portugal, Lisboa, Edições Salamandra, 1987; Maria Isabel Ribeiro de Faria e Paulino Mota Tavares, «Aspectos de comer e estar à mesa no século XVII português», Boletim do Arquivo da Universidade de Coimbra, vol. X, 1990, pp. 271-311; Carlos Veloso, A Alimentação em Portugal no Século XVIII nos Relatos de Viajantes Estrangeiros, Coimbra, Minerva, 1992; Rui Martins, «A alimentação medieval: práticas e representações», Revista de Ciências Históricas, Univ. Portucalense, vol. VII, 1993, pp. 67-82; Alfredo Saramago, A Caça: perspectiva Histórica e Receitas Tradicionais, Sintra, Colares Editora, 1994; Maria Manuel Torrão, Dietas Alimentares. Transferências e adaptações nas Ilhas de Cabo Verde (1450-1540), Lisboa, Instituto de Investigação Científica Tropical, 1995; João Pedro Ferro, Arqueologia dos Hábitos Alimentares, Lisboa, D. Quixote, 1996; Maria José Palla, «Manger er boire au Portugal à la fin du Moyen Age - texte et image», in Banquets et Manières de Table au Moyen Age, Aix-en-Provence, CUER-MA, 1996, pp. 93-123; idem, «Cozinhar é contar uma história. O imaginário alimentar em Gil Vicente», in Actas do Quinto Congresso da Associação Internacional de Lusitanistas, Oxford - Coimbra, 1998, pp. 1187-2000; Livros Portugueses de Cozinha, coord. e pesquisa bibliográfica de Manuela Rego, $2^{\mathrm{a}}$ edição, Lisboa, Biblioteca Nacional, 1998; Rui Rocha, A Viagem dos Sabores. Ensaio sobre a História da Alimentação (séculos IX-XIX) seguido de 100 Receitas em que vários mundos se encontram, Lisboa, Inapa, 1998; Carlos Consiglieri e Marília Abel, A tradição Conventual na doçaria de Lisboa, Sintra, Colares Editora, 1999; Paulino Mota Tavares, Mesa, Doces e Amores no século XVII português, Sintra, Colares Editora, 1999; Alfredo Saramago e Homem Cardoso, Para a História da Doçaria Conventual Portuguesa, Lisboa, CTT, 2000; Maria Manuela Catarino, «A carne e o peixe nos recursos alimentares das populações do Baixo Tejo», in Animalia. Presença e Representações, coord. Miguel Alarcão, Luís Krus e Maria Adelaide Miranda, Lisboa, Edições Colibri, 2002, pp. 49-59; Isabel M. R. Drumond Braga, Portugal à Mesa. Alimentação, Etiqueta e Sociabilidade, 1800- 1850, Lisboa, Hugin, 2000; idem, Do Primeiro Almoço à Ceia: Estudos de História da Alimentação, Sintra, Colares Editora, 2004; Paulo Drumond Braga, Leite. Biografia de um Género Alimentar, Sintra, Colares Editora, 2004.

9 A. H. de Oliveira Marques, A Sociedade Medieval Portuguesa. Aspectos de Vida Quotidiana, $4^{a}$ edição, Lisboa, Sá da Costa, 1981, pp. 7-22; Introdução à História da Agricultura em Portugal. A Questão Cerealífera durante a Idade Média, $3^{\mathrm{a}}$ edição, 1987; idem e João Pedro Ferro, «L'alimentation au Portugal du Moyen Age au XVIIIe siècle», in La Sociabilité à Table..., pp. 283-291. 
Dias Arnaut ${ }^{10}$, Iria Gonçalves ${ }^{11}$, Maria Helena da Cruz Coelho ${ }^{12}$ e Maria José Azevedo Santos ${ }^{13}$, cujos estudos fizeram, nuns casos, ou têm feito, noutros, avançar de forma substantiva o conhecimento sobre a alimentação em tantas e diferenciadas vertentes como a produção e os mercados, padrões de consumo, hábitos, gostos e predilecções alimentares e culinárias, receituários, mesa e hierarquia social, desenvolvimentos acompanhados e sustentados pela publicação de fontes documentais diferenciadas e testemunhos de grande e decisiva importância para a afirmação deste campo de estudos entre nós.

Procurando integrá-los numa reflexão mais geral sobre a mesa no quotidiano e nos cerimoniais da corte, este estudo procura evidenciar alguns dos padrões de consumo alimentar na corte portuguesa do século XVI, com particular relevo para a corte de D. João III (1521-1557). Quer isto dizer, desde logo, que o ponto de vista que escolhemos para reflectir sobre a alimentação, ou seja, sobre um acto e uma prática comuns a todos os homens em todos os tempos,

${ }^{10}$ Salvador Dias Arnaut, A Arte de Comer em Portugal na Idade Média (Introdução a $O$ 'Livro de Cozinha' da Infanta D. Maria de Portugal), Lisboa, IN-CM, 1986. Nova edição na Colares Editora, 2000. O Livro de Cozinha da Infanta D. Maria foi publicado no mesmo ano de 1986 com Prólogo, Leitura, Notas aos Textos, Glossário e Índices por Giacinto Manuppella, Lisboa, IN-CM. Tradução para francês de Maria José Palla, Livre de Cuisine de l'Infante Maria du Portugal femme d'Alexandre Farnèse, Lisboa, FCSH, Instituto de Estudos Medievais, 2008.

${ }^{11}$ Iria Gonçalves, entre outros estudos: «Acerca da alimentação medieval», in Imagens do Mundo Medieval, Lisboa, Livros Horizonte, 1988, pp. 201-213; «A colheita régia medieval, padrão alimentar de qualidade (um contributo beirão)», in Revista da Faculdade de Ciências Sociais e Humanas, n. 6, 1992-93, pp. 175-189; «Defesa do Consumidor na Cidade Medieval: os Produtos Alimentares (Lisboa, séculos XIV-XV)», Um Olhar sobre a Cidade Medieval, Cascais, Patrimonia, 1996, pp. 97-116; «À Mesa, com o Rei de Portugal (séculos XII-XIII)», Revista da Faculdade de Letras. História, Porto, $2^{\mathrm{a}}$ série, vol. XIV, 1997, pp. 15-32; «Sobre o pão medieval minhoto: o testemunho das Inquirições de 1258», Arqueologia Medieval, n. 6, 1999, pp. 225-243; «A alimentação medieval: conceitos, recursos, práticas», in Actas dos VI Cursos Internacionais de Verão de Cascais, vol. II, A Alimentação, Cascais, Câmara Municipal de Cascais, 2000, pp. 29-48; «Entre a abundância e a miséria: as práticas alimentares da Idade Média Portuguesa», in Estudos Medievais. Quotidiano Medieval: Imaginário, Representação e Práticas, coord. Amélia Aguiar Andrade e José Custódio Vieira da Silva, Lisboa, Livros Horizonte, 2004, pp. 42-65; «A propósito do pão da cidade na Baixa Idade Média», História da Alimentação, Turres Veteras, IX, Lisboa, Edições Colibri, 2007, pp. 49-72.

${ }^{12}$ Maria Helena da Cruz Coelho, «Apontamentos sobre a comida e a bebida do campesinato coimbrão em tempos medievos», in Homens, Espaços e Poderes (séculos XI-XVI), vol. I - Notas do Viver Social, Lisboa, Livros Horizonte, 1990, pp. 9-22; «Receitas e Despesas do Mosteiro de Santa Cruz de Coimbra, em 1534-1535», in Idem, vol. II - Domínio Senhorial, pp. 93-119.

13 Maria José Azevedo Santos, A Alimentação em Portugal na Idade Média. Fontes, Cultura, Sociedade, Coimbra, Tip. Lousanense, 1997, onde se coligem importantes estudos sobre o tema; Jantar e Cear na Corte de D. João III. Leitura, Transcrição e Estudo de Dois Livros da Cozinha do Rei (1524 e 1532), Vila do Conde - Coimbra, Câmara Municipal de Vila do Conde, Centro de História da Sociedade e da Cultura, 2002; «A escrita serve à mesa. Um valioso livro da ucharia da casa d' El Rei D. João III», Actas do VI Congresso Galiza - Norte de Portugal, Chaves, 2005, pp. 23-65. 
é o relativo a um meio social bem definido, a corte régia, num tempo e num espaço também eles determinados, o Portugal de Quinhentos.

Tal clarificação é imprescindível já que, pela própria natureza do tema, só desta forma é possível distinguir práticas transversais e fundamentalmente idênticas no conjunto da sociedade, daquelas que eram exclusivas dos meios aristocráticos, da corte e do rei, ou que pelo menos aí adquiriam formas, manifestações e significados próprios. Este facto torna-se claro, por exemplo, quando, constatando o evidente significado simbólico que, de uma maneira ou outra, envolve sempre o acto de comer, percebemos que no caso da realeza, como já foi sublinhado por antropólogos e historiadores, esse significado podia, no limite, incorporar uma dimensão litúrgica e até sacral ${ }^{14}$.

Em segundo lugar, é ainda possível discernir, numa afirmação que é válida para o mundo medieval e moderno, uma dimensão política na alimentação do rei. Devemos a este propósito ter presente que, de forma ideologicamente muito enraizada nas representações políticas e na tratadística sobre o ofício régio desde a época medieval, a comunidade política era concebida e muitas vezes representada à imagem do corpo humano, sendo indissolúvel o vínculo entre a cabeça, ou seja, o rei, e o corpo da república ${ }^{15}$; numa tal concepção corporativa

${ }^{14}$ Sergio Bertelli, Il Corpo del Re. Sacralità del Potere nel'Europa Medievale e Moderna, Florença, Ponte Alle Grazie, 1990, pp. 164-185; Marzio A. Romani, «Regalis coena: aspetti economici e sociali del pasto principesco (Italia settentrionale secoli XVI-XIX)», in Alimentazione e Nutrizione..., p. 721.

${ }^{15}$ Sobre a origem, transformações e apropriações do conceito de corpus mysticum na época medieval, a obra de referência continua a ser o clássico estudo de Ernst Kantorowicz, The King's two Bodies. A Study in Medieval Political Theology (1957; edição consultada: Los dos cuerpos del rey. Un estudio de teología política medieval, Madrid, Alianza Editorial, 1985), especialmente o capítulo V, «La realeza politicentrica: corpus mysticum», pp. 188-259. Ver também Otto Gierke, Political Theories of the Middle Age, Cambridge, 1987 ( $1^{\mathrm{a}}$ edição alemã 1900), «IV. The Idea of Organization», pp. 22-30 e notas, pp. 129-137; A.-H. Chroust, «The Corporate Idea and the Body Politic in the Middle Ages», The Review of Politics, vol.IX, 1947, pp. 423-452; Richard H. e Mary Rouse, «John of Salisbury and the Doctrine of Tyrannicide», Speculum, 42, 1967, n. 4, pp. 693709. Particularmente no que respeita ao mundo hispânico, José Antonio Maravall, «La idea de cuerpo mistico en España antes de Erasmo», in Estudios de Historia del Pensamiento Español, I, Edad Media, $3^{\text {a }}$ edição, Madrid, Ediciones Cultura Hispanica, 1983, pp. 179-199, e José Manuel Nieto Soria, Fundamentos Ideológicos del Poder Real en Castilla (Siglos XIII-XVI), Madrid, Ediciones de la Universidad Complutense, 1988, pp. 90-99. No que respeita à vitalidade da analogia do corpo na Época Moderna, veja-se o excelente estudo de Paul Archambault, «The Analogy of the 'Body' in Renaissance Political Literature», Bibliothèque d'Humanisme et Renaissance, t. XXIX, 1967, pp. 21-53; Henri Weber, «L'analogie corps humain-corps social dans la pensée politique du XVIe siècle», Analogie et Connaissance, I - Aspects Historiques, Paris, Maloine Éditeur, 1980, pp. 139-148; Ralph Giesey, Cérémonial et Puissance Souveraine. France, XVe-XVIIe siècles, especialmente cap. I, Paris, Armand Colin, 1987, pp. 9-19; Claude Gandelman, «Le corps du roi comme 'carte du royaume'», in Idéologie et Propagande en France. Colloque de l'Université d'Haifa, Paris, Picard, 1987, pp. 19-27; Le Corps comme Métaphore dans l'Espagne des XVIe et XVIIe siècles. Du Corps Métaphorique aux Métaphores Corporelles. Colloque 
da sociedade, tudo o que o monarca era e fazia, todas as suas virtudes ou todos os seus vícios, se repercutiam na comunidade política. A esta luz, e à luz de uma relação indissolúvel entre o «corpo natural» e o «corpo místico» do rei, tal como a educação intelectual, religiosa ou a aquisição das virtudes, também o corpo do monarca, e todas as práticas relativas à conservação da sua saúde física e sustento, como é o caso da alimentação, comportavam uma dimensão política. No limite e em síntese, como observa Georges Vigarello, numa História do Corpo recentemente editada, «L'histoire du corps du roi est bien aussi celle de l'État» ${ }^{16}$.

Num outro plano mais imediatamente visível era ainda político o alimento do rei. Na verdade, no âmbito dos mecanismos de afirmação e de celebração do poder da realeza que, entre o mundo medieval e o mundo moderno, se foram enraizando e ganhando protagonismo, a mesa ocupava um lugar preponderante e de privilégio. Da comida e da mesa do rei eram indissociáveis a ostentação e o luxo, a fartura e a abastança, os rituais e as hierarquias, numa afirmação da distinção, singularidade e poder que, não sendo dela exclusivos -lembremos o caso da corte papal- eram próprios da realeza ${ }^{17}$. São estes, pois, alguns dos tópicos que temos de ter presentes, ou que pelo menos devem estar subjacentes, quando reflectimos sobre a mesa do rei na época que consideramos. Reflexão que, sendo necessário inscrever numa perspectiva mais vasta e implicando o cruzamento necessário entre vários saberes e campos de análise, será aqui vista sob um prisma particular e preciso, que é o dos consumos, em articulação com aspectos cerimoniais e da simbólica alimentar.

Aproximemo-nos, pois, do nosso objecto, situando-nos num momento particular, o Portugal de Quinhentos, e num lugar determinado, a corte de D. João III, recorrendo para tal a um conjunto de testemunhos que nos permitem lançar um olhar sobre aquilo a que, de uma forma genérica, designamos como a «mesa

International (Sorbonne et Collège d'Espagne, 1-4 Octobre 1990), Etudes réunies et présentées par Augustin Redondo, Paris, Publications de la Sorbonne Nouvelle, 1992, particularmente os estudos incluídos nas I e II Partes, «Aspects politiques et sociaux», pp. 9-139; António Manuel Hespanha e Ângela Barreto Xavier, «A representação da sociedade e do poder. Paradigmas políticos e tradições literárias», in História de Portugal, dir. José Mattoso, IV - O Antigo Regime (1620-1807), coord. António M. Hespanha, Lisboa, Círculo de Leitores, 1993, pp. 121-125; Ana Isabel Buescu, Imagens do Príncipe. Discurso Normativo e Representação, Lisboa, Cosmos, 1996, pp. 64-65, pp. 387-409.

${ }^{16}$ Georges Vigarello, «Le corps du roi», in Histoire du Corps, dir. Alain Corbin, JeanJacques Courtine, Georges Vigarello, 1 - De la Renaissance aux Lumières, dir. Georges Vigarello, Paris, Seuil, 2005, p. 409.

${ }^{17}$ Ver o conjunto de estudos de Martin Aurell, N. Gauthier, C. Virlouvet, Jacques Le Goff, J. Allard, J. Alves Dias e M. del Cármen Simon nas Actas do já citado Colóquio La Sociabilité à Table..., pp. 117-170, e ainda, numa reflexão integrada no conjunto dos mecanismos do poder ritual da monarquia, Carmelo Lisón Tolosana, La Imagen del Rey (Monarquia, Realeza y Poder Ritual en la Casa de los Austrias), Madrid, Espasa-Calpe, 1991. 
do rei»-realidade que, em vários dos seus elementos estruturantes, podemos rastrear desde os tempos medievais ${ }^{18}$. Comecemos pelos produtos que aí eram consumidos. Segundo um livro de cozinha do rei relativo ao ano de 1524, publicado por Maria José Azevedo Santos, a carne era, de longe, o alimento mais comprado e consumido na corte joanina. Tal facto não constituía novidade, e confirma, se necessário fosse, que o consumo de carne era um elemento de distinção associado a um maior poder económico e ao próprio lugar do indivíduo na hierarquia social. Se a base tradicional da alimentação era o pão -também ele símbolo de diferenciação social- presente com fartura na mesa do rei e confeccionado com o cereal nobre, a farinha de trigo, a carne fazia parte integrante e destacada da alimentação dos estratos mais elevados da sociedade, $o$ que é o mesmo que dizer da corte régia e dos meios aristocráticos ${ }^{19}$.

A própria tradição literária acolhia, desde a Idade Média, as diferenças simbólicas, sociais e até espirituais entre práticas alimentares diferenciadas. Num estudo que pretende elucidar os códigos e elementos de uma simbólica alimentar na época medieval tomando como campo de análise o ciclo dos romances arturianos, Anita Guerreau-Jalabert estabelece, de forma expressiva, uma tipologia contrastiva entre o que classifica de «triângulo alimentar cavaleiresco» -pão, vinho, carne- e o «triângulo alimentar eremítico», constituído pelo pão, água e vegetais ${ }^{20}$. Também médicos e dietistas dos séculos XVI e XVII, erguendo um discurso de advertência sanitária em torno das práticas alimentares de reis e senhores, não deixavam de assinalar a diferença do valor nutritivo dos produtos consumidos, sendo que, indiscutivelmente, o lugar cimeiro entre estes era ocupado pelo pão, vinho e carne ${ }^{21}$.

Assim, de acordo com o citado livro de cozinha de 1524, a carne de vaca teve um lugar de absoluto destaque nos consumos da corte, tendo dado entrada na ucharia régia, naquele ano, $3200 \mathrm{Kg}$; a carne de porco era também muito

${ }^{18}$ Particularmente para este aspecto, ver o estudo de Iria Gonçalves, «À Mesa, com o Rei de Portugal».

${ }^{19}$ Como observava Marc Bloch a propósito do «pão branco» e do «pão negro», «A travers les siècles, point de critère de classe plus net que celui-là». «Les aliments de l'ancienne France», in Cahiers des Annales, 28, Pour une Histoire de l'Alimentation, ob cit., p. 232 ; Iria Gonçalves, «A propósito do pão da cidade...». ob. cit.

${ }^{20}$ Anita Guerreau-Jalabert, «Aliments symboliques et symbolique de la table dans les romans arthuriens (XII-XIII siècles)», Annales E.S.C., mai-juin 1992, n. 3, pp. 561-594; ainda da mesma autora, «Les nourritures comme figures symboliques dans les romans arthuriens», in La sociabilité à table..., p. 37. Sergio Bertelli, ob. cit., pp. 164-167. A importância dos romances medievais como fonte privilegiada para o conhecimento de ideias, práticas, códigos e cerimoniais alimentares e culinários é destacado, para o caso da Inglaterra medieval, por Madeleine Pelner Cosman, Fabulous Feasts. Medieval Cookery and Ceremony, Nova Iorque, George Braziller, 1976.

${ }^{21}$ Jeanne Allard, «Le corps vu par les traités de diététique dans l'Espagne du Siècle d'Or», in Le Corps dans la Société Espagnole des XVI et XVII Siècles, Colloque International (Sorbonne, 5-8 octobre 1988), Etudes réunies et présentées par Augustin Redondo, Paris, Publications de la Sorbonne, 1990, pp. 96-97. 
apreciada $^{22}$, mas o seu consumo foi muito menor, rondando os $500 \mathrm{Kg}$; na ucharia entraram também toucinho, o carneiro, carne tão apreciada em toda a cozinha mediterrânea ${ }^{23}$, que os médicos louvavam aliás pela sua fácil digestão, ao contrário da carne de vaca ${ }^{24}$, bem como caça e galinhas. No que respeita à caça, a carne mais consumida na corte portuguesa nesta época foi a perdiz, que surgia à mesa quase sempre cozida -como sucedia com a carne de vaca- mas há também uma expressiva referência a pombos e coelhos. A galinha era outro alimento habitual na alimentação da corte, surgindo quer em cozinhados doces quer salgados, assim como os ovos, que se consumiam em quantidades muito apreciáveis -nesta sua estadia em Évora, a corte de D. João III consumiu, em apenas 22 dias, mais de 113 dúzias de ovos nas mais variadas receitas, doces e salgadas $^{25}$.

Associado, simbolicamente, a situações e a momentos de maior frugalidade, o pescado, muito variado, raramente fresco, mas sobretudo seco, fumado ou salgado, e ainda o marisco, estavam também presentes na mesa do rei. No quadro de uma inequívoca supremacia do consumo de carnes, peixes e mariscos surgiam à mesa do rei de acordo com várias condicionantes, com destaque para as que decorriam do calendário litúrgico, que ao longo do ano determinava uma apertada «grelha» de muitos períodos de jejum e abstinência. Como observa Maria José Azevedo Santos, o «abundante e variado consumo de carnes» que caracterizava o padrão dominante de consumo nas camadas superiores da sociedade quinhentista, era só quase «interrompido pelos preceitos de abstenção a que a Igreja obrigava todos os fiéis» ${ }^{26}$. Claro que também existiam outras circunstâncias que proporcionavam um maior consumo de peixe, numa sociedade marcada pelas dificuldades nos abastecimentos que, embora mais agudas nos tempos medievais ${ }^{27}$, se mantinham no século de Quinhentos e se relacionavam com o aprovisionamento em função quer da época do ano quer do lugar em que se encontrava a corte. Não deixa de ser significativo a este propósito constatar que em 1524, estando a corte em Évora, o peixe mais consumido foi a humilde sardinha, normalmente ausente das mesas mais

${ }^{22}$ Note-se que, em relação à carne de porco, para além do estrito gosto culinário, havia, na época, ainda uma outra crucial dimensão, de natureza bem diferente, que articulava razões de ordem religiosa e simbólica no consumo ou na abstinência da carne deste animal: comer carne de porco fazia prova, para qualquer um, da sua condição de cristão; abster-se ostensivamente do seu consumo era considerado «prova» de judaísmo.

${ }^{23}$ Iria Gonçalves, «À Mesa, com o Rei de Portugal», ob. cit., p. 20.

${ }^{24}$ Jeanne Allard, ob. cit., pp. 97-98. Ver as considerações sobre as várias carnes e a sua digestibilidade no Pseudo-Aristóteles, Segredo dos Segredos, tradução portuguesa, segundo um manuscrito inédito do séc. XV, Introdução e notas de Artur Moreira de Sá, Lisboa, Publicações da Faculdade de Letras da Universidade de Lisboa, 1960, p. 40.

${ }^{25}$ Maria José Azevedo Santos, «Jantar e Cear...», p. 41.

${ }^{26}$ Ibidem, p. 42-43.

${ }^{27}$ Iria Gonçalves, «À Mesa, com o Rei de Portugal...», p.17. 
abastadas $^{28}$. Finalmente, também em relação ao peixe a dominante teoria dos humores da medicina galénica sustentava o carácter pouco nutritivo -daí a sua adequação aos jejuns a que a Igreja obrigava- do peixe, a que atribuía um humor frio e húmido, considerado nocivo à saúde ${ }^{29}$.

No dia 1 de Novembro desse ano, evidenciando a absoluta preeminência das carnes, e a sua variedade e abundância na alimentação aristocrática ${ }^{30}$, o rei D. João III teve à mesa, à ceia, cerca de dois quilos de carne de vaca e um de lombo, duas perdizes, dois pombos e um coelho; mas no dia 19 do mesmo mês, dia «magro» de abstinência, o cardeal D. Afonso, irmão do monarca, viu seremlhe servidos, ao jantar e à ceia, 6 linguados, 24 azevias $^{31}, 12$ salmonetes, 1 pargo, $1 / 2$ congro e 4 santolas $^{32}$. A convicção que fica é a de que o peixe era, por razões várias, quase uma «inevitabilidade» que não concorria, em termos de predilecção alimentar e significado simbólico, entre as elites, com o consumo da carne. Já na segunda metade do século XVI, o embaixador de Veneza na corte espanhola observava a compleição delicada de Filipe II, que se alimentava habitualmente de manjares substanciais e, depreende-se, considerados verdadeiramente nutritivos e adequados à manutenção da saúde, «no comiendo ni pescado ni fruta, ni nada parecido que engendre malos humores $»^{33}$. $\mathrm{O}$ verdadeiro e nobre alimento era, sem dúvida, a carne.

Na corte joanina eram também muito apreciados os pastéis e as empadas, de já longa tradição, feitas quer de peixe ${ }^{34}$ quer de carne. O chamado Livro de Cozinha de D. Maria, que pertenceu à princesa portuguesa, neta de D. Manuel ${ }^{35}$, que em 1565 casou com o príncipe Alexandre Farnese, integra várias receitas da tradição culinária da corte portuguesa, permitindo um olhar mais próximo sobre

${ }^{28}$ Maria José Azevedo Santos, Jantar e Cear..., p. 44.

${ }^{29}$ A teoria dos quatro humores corporais - sangue, fleuma, bílis amarela e bílis negra, que procediam, respectivamente, do coração, cérebro, fígado e baço - constituiu, desde Hipócrates (c. 460-377aC) e Galeno (c. 131-c. 200), o principal fundamento da medicina e de explicação do funcionamento do corpo humano até ao século XVII. Cada um dos humores tinha diferentes características: o sangue era quente e húmido, a fleuma fria e húmida, a bílis amarela, quente e seca, e a bílis negra fria e seca. Do predomínio de um ou outro humor no organismo humano resultavam os diferentes tipos fisiológicos: o sanguíneo, o fleumático, o bilioso ou colérico e o melancólico. Considerava-se que todas as doenças eram causadas pela alteração do equilíbrio entre os humores, sendo que a alimentação desempenhava uma função primordial nesse equilíbrio - ou na falta dele, e portanto na saúde e na doença. Como se compreende, qualquer abordagem das práticas alimentares nas épocas medieval e moderna tem de ter presente este crucial quadro explicativo.

${ }^{30}$ Iria Gonçalves, «À Mesa, com o Rei de Portugal...», p. 21.

${ }^{31}$ Peixe semelhante ao tão apreciado linguado, frequente nas costas portuguesas.

${ }^{32}$ Maria José Azevedo Santos, Jantar e Cear... p. 47.

${ }^{33}$ Cit. por Jeanne Allard, ob. cit., p. 99.

${ }^{34}$ Maria José Azevedo Santos, Jantar e Cear..., pp. 45-46.

${ }^{35}$ Filha do infante D. Duarte (†1540), irmão de D. João III, e de D. Isabel (†1576), irmã de D. Teodósio, $5^{\circ}$ duque de Bragança. 
as iguarias que eram confeccionadas para deleite de reis e de nobres e, até, averiguar orientações e inclinações dos gostos culinários. No «caderno dos manjares de carne», encontramos, entre várias outras, delicadas receitas de pastéis de carne, de tutanos, de fígados de cabrito ou de pombinhos, tigeladas de perdiz, galinha mourisca, galinha alardada ${ }^{36}$ e galinha albardada, coelho em tigela, várias receitas de coelho e láparo ${ }^{37}$. Lugar destacado neste livro de receitas ocupam também, reflectindo o lugar que tinham nos consumos da corte portuguesa, os «manjares de ovos» ${ }^{38}$ e os «manjares de leite», onde encontramos iguarias como o célebre manjar-branco, uma das mais apreciadas sobremesas na época, pastéis de leite, beilhós ${ }^{39}$ de arroz e tigeladas.

Testemunho eloquente de como, no universo da sociabilidade feminina, também nas casas aristocráticas a troca de receitas era muitas vezes sinal de amizade e distinção, aqui encontramos duas receitas atribuídas a uma D. Isabel de Vilhena -as tigeladas de leite e as tão apreciadas almojávenas, tortas fabricadas com massa de farinha e queijo ou requeijão ${ }^{40}$, de origem mourisca ${ }^{41}$. A maior secção deste livro de receitas diz, contudo, respeito a uma outra área de imensa importância na culinária de então- as conservas, doces e salgadas, o que se compreende, se atendermos às precárias condições da conservação dos alimentos: desde a Antiguidade, todas as tradições culinárias, sem excepção, davam um lugar de destaque a tais práticas ${ }^{42}$. No «caderno das cousas de conservas», sucedem-se minuciosas e delicadas receitas de doces e conservas de cidra, limão, peras, pêssegos em calda, receitas várias de marmelada -uma atribuída a Cesária Ximenes, outra a uma D. Joana-, pontos de açúcar, mas também fartos e biscoitos, o afamado maçapão, ou o tão apreciado e omnipresente pão-de-lót ${ }^{43}$, evidenciando como na mesa de reis e senhores abundavam, também, as «cousas de açúcar»" ${ }^{44}$.

Interessante se torna também observar este livro de cozinha sob um outro ponto de vista, que também nele tem lugar, embora de forma discreta. Se para nós, hoje, falar de culinária e de receitas respeita a uma actividade e a um objecto

${ }^{36} \mathrm{Ou}$ seja, lardeada com toucinho.

${ }^{37}$ Livro de Cozinha..., ed. Giacinto Manupella, ob. cit., pp. 9-53.

${ }^{38}$ Idem, pp. 55-63.

${ }^{39} \mathrm{Ou}$ belhó, espécie de filhó feita de abóbora doce, farinha e vários condimentos. Ib., p. 176.

${ }^{40} \mathrm{Ib} ., \mathrm{pp} .65-83$ e p. 171.

${ }^{41}$ Pedro Plasencia, A la mesa con don Quijote y Sancho, Madrid, Punto de Lectura, 2005, p. 185.

${ }^{42}$ Lucie Bolens, «Sciences Humaines et Histoire de l'alimentation: conservation des aliments et associations des saveurs culturelles (de l'Andalousie à la Suisse Romande)», in Alimentazione e Nutrizione..., pp. 387-422; Bruno Laurioux, A Idade Média à Mesa, Lisboa, Europa-América, 1992, pp. 63-64.

${ }^{43}$ Livro de Cozinha..., pp. 85-149.

${ }^{44}$ Damião de Góis, Crónica do Felicíssimo Rei D. Manuel, nova edição conforme a primeira de 1566, Coimbra, Universidade de Coimbra, P. IV, 1955, cap. 84, p. 225. 
bem delimitados, no século XVI acontecia com frequência os receituários terem um alcance bem mais amplo, respeitando a uma «constelação» de saberes relativos a muitas situações do quotidiano. Transmitidos sobretudo pela tradição oral, esses saberes eram, desde a Idade Média, objecto de compilação através de manuais e livros de «segredos» e receitas destinados a um público feminino. Tratava-se, afinal, de verdadeiras miscelâneas sobre matérias relativas à medicina doméstica, higiene, cosmética, cozinha e alimentação, incluindo, por vezes de forma aparentemente aleatória, receitas de perfumes, preparados e mezinhas para o cabelo, sabões para o rosto e mãos, pós para os dentes, unguentos, bálsamos e outros cremes, remédios para certas enfermidades, verrugas e borbulhas, mau hálito e manchas na pele ${ }^{45}$ e receitas culinárias. Por vezes, como sucede com um receituário que terá pertencido à princesa D. Joana, mãe de D. Sebastião, até indicações astrológicas ${ }^{46}$. Exemplo particularmente expressivo deste tipo de compilações, sensivelmente para a época e meio social que nos ocupam, é o anónimo Manual de Mugeres en el qual se Contienen Muchas y Diversas Reçeutas muy Buenas ${ }^{47}$. No caso do livro de receitas de D. Maria, a tónica é inegavelmente culinária, mas não deixa de aflorar essa outra componente, através de três receitas -uma de um D. Luís de Moura para as dores de dentes, outra para as dores de garganta e uma outra directamente relacionada com a cozinha e a actividade culinária, para tratar queimaduras ${ }^{48}$. No citado Manual de Mugeres, ao contrário, predominando preparados, sabões, unguentos e remédios, não faltam receitas para fazer chouriços, biscoitos, os apreciados «buñuelos $»^{49}$ e maçapão, conservas, caldos, molhos e outras iguarias ${ }^{50}$.

Um outro testemunho de interesse relativo à mesa de D. João III prende-se com uma deslocação do monarca a Tomar. Em 1550, D. João III, que tão profundamente interviera, muitos anos antes, na reforma da Ordem de Cristo ${ }^{51}$, foi solenemente recebido no Convento em Tomar, onde lhe foi oferecido um lauto banquete pelos freires. Entre as iguarias, encontrava-se uma grande variedade de peixes, entre os quais atum, cherne, corvina, linguado, mas também aves, vaca, coelhos e cabritos, ovos e galinhas em abundância, além de acessórios necessários -cadeira de espaldar para o rei, toalhas de holanda- que

${ }^{45}$ BGUC, cod. 160.

${ }^{46}$ BNP, cod. 10761 , fols. $38 \mathrm{v}-39 \mathrm{v}$.

${ }^{47}$ Manual de Mugeres en el qual se Contienen Muchas y Diversas Reçeutas muy Buena, estudio, ed. y notas de Alicia Martinez Crespo, Salamanca, Ediciones Universidad de Salamanca, 1996.

${ }^{48}$ Livro de Cozinha..., pp. 145-149. *qual?

${ }^{49}$ Espécie de farturas, que ainda hoje são confeccionadas.

${ }^{50}$ Ver supra, nota 47, pp. 53, 57, 59.

${ }^{51}$ Fernanda Olival, «Structural Changes within the $16^{\text {th }}$ Century at Portuguese Military Orders», E-Journal of Portuguese History, vol. 2, number 2, winter; Ana Isabel Buescu, D. João III (1502-1557), Lisboa, Temas \& Debates, 2008, pp. 235-236. 
implicaram para os freires despesas de monta $^{52}$. Durante a visita que os reis realizaram a Coimbra nesse mesmo ano, onde foram recebidos no mosteiro de Santa Cruz e na Universidade, nas suas deambulações pelas várias dependências do mosteiro a rainha D. Catarina e a infanta D. Maria, irmã do monarca, quiseram ver o refeitório; demoraram-se em particular a ver fritar uns linguados, pedindo a rainha que lhos mandassem para a ceia do rei; à merenda, na casa da livraria do coro, serviram-se galinhas assadas, os ditos linguados e muitas frutas e doces ${ }^{53}$.

Singularmente ausente está a referência aos legumes entre as iguarias e manjares que vão à mesa do rei. Na verdade, legumes e frutas não tinham um idêntico peso social. Enquanto as frutas, apesar de certa reserva por parte de alguns médicos ${ }^{54}$, eram parte integrante da dieta aristocrática, sendo consumidas frescas, secas ou em conserva, os legumes e hortaliças, considerados como iguaria «magra», não eram apreciados por reis e nobres e encontravam-se ausentes da sua mesa ${ }^{55}$. Segundo Jean-Louis Flandrin, foi sensivelmente a partir do século XVI que os legumes, humildes frutos da terra, cujo consumo era considerado próprio das camadas inferiores da sociedade durante a Idade Média, se foi tornando um elemento de distinção, ganhando progressiva, embora lenta, visibilidade e favor nas mesas mais requintadas e socialmente mais elevadas ${ }^{56}$. Além de que, como já tivemos ocasião de aludir atrás, existia ainda uma razão de ordem sanitária que, no âmbito da então dominante e indiscutida medicina galénica, associava a esses produtos, em particular alguns legumes e vegetais, mas também algumas frutas, uma interferência negativa nos humores e na qualidade do sangue ${ }^{57}$; ou, ainda, a convicção, também ela enraizada na sociedade medieval, que vira nascer e difundir-se a «cultura do horto» e uma importante farmacologia herborística ${ }^{58}$ de que alguns legumes, ervas e frutas

52 João Alves Dias, «Un banquet royal au Portugal au XVIe siècle», in La Sociabilité à Table ..., pp. 155-157 ; Paulo Drumond Braga, D. João III, Lisboa, Hugin, 2002, pp. 83-84.

${ }_{53}$ Augusto Mendes Simões de Castro, Vinda de El-Rei D. João $3^{\circ}$ a Coimbra no ano de 1550, e do modo como foi recebido pela Universidade, separata do «Boletim Bibliográfico da Biblioteca da Universidade», Coimbra, vol. I, 1914, p. 22.

${ }^{54}$ Como o doutor Lobera de Ávila, médico de Carlos V.

${ }^{55}$ Iria Gonçalves, «À Mesa, com o Rei de Portugal...», p. 23. Pedro Plasencia, ob. cit., pp. 176-179. P. W. Hammond constata a quase ausência de menção a legumes nos menus dos banquetes régios em Inglaterra nos finais da Idade Média. P.W. Hammond, Food and Feast in Medieval England, Phoenix Mill, Alan Sutton, 1996, pp. 130-142.

${ }^{56}$ Jean-Louis Flandrin, «Pour une histoire du goût», in La Cuisine et la Table. 5000 ans de Gastronomie, n. especial de L'Histoire, 85, 1986, p. 13; Bruno Laurioux, A Idade Média à Mesa..., pp. 51-52. Veja-se, por exemplo, a controvérsia em torno das virtudes e malefícios da cebola ou o caso do alho, indissociavelmente ligado à vilania, ainda em tempos do Quijote. Pedro Plasencia, A la mesa con don Quijote..., pp. 66-72 e 75-77.

57 Jeanne Allard, ob. cit., pp. 98-99. Ver supra, nota 29.

${ }^{58}$ Massimo Montanari, Alimentazione e cultura ..., pp. 206-213. 
eram sobretudo úteis na confecção de mezinhas para tratar as mais variadas afecções, febres e doenças -uma manhã, dois físicos de D. João III discutiam «em grande porfia» qual a melhor dieta para um doente acometido por febres, se alface cozida se maçã assada; da acesa discussão deu João de Sá, o Negro, bobo do rei, conta ao monarca que, curioso, mandou chamar os médicos para, na sua presença, decidirem sobre tão magna questão ${ }^{59}$.

Um outro livro da ucharia da casa de D. João III, também recentemente publicado por Maria José Azevedo Santos ${ }^{60}$, revela-se precioso, através de uma escrituração minuciosa das despesas, nas referências aos produtos consumidos pela casa do rei, numa ocasião que, apesar de não identificada nem datada, foi certamente de grande solenidade, envolvendo uma grande dimensão de meios. Embora a análise do documento não permita uma datação rigorosa, todas as movimentações de que nos dá conta, nomeadamente no que se refere às despesas com o transporte, de Lisboa para Belém, de grandes quantidades de bens alimentares de todo o género, mas também de louças e móveis de aparato, tapeçarias e «panos d'armar», e despesas com oficiais e criadagem, se referem à estadia da corte e aos preparativos de uma cerimónia de grande solenidade a ter lugar em Belém.

No que diz respeito aos produtos alimentares, aí encontramos grandes quantidades de carne de vaca e vitela, carneiros e perdizes, galinhas e frangãos, pombinhos e coelhos, lebres e láparos, toucinhos, sáveis, linguados, azevias, rodovalhos e pescadas, queijos do Alentejo, requeijão e queijos frescos, couves e cheiros, alcaparras e mostarda, laranjas, limões, cerejas, barris de fruta de conserva, «passa d'Alicante», «açúcar da Ilha da Madeira» e «açúcar do Brasil», farinha, ovos, vinhos tinto e branco, vinagre rosado, azeite e mantequilhas ${ }^{61}$ e até «fersuras para os gatos»... Vivendo ainda D. João III, arriscamos que possa dizer respeito a uma das maiores cerimónias públicas da monarquia durante o seu reinado: referimo-nos à grandiosa cerimónia de trasladação dos corpos dos reis D. Manuel e D. Maria, pais do monarca, bem como dos infantes seus irmãos, para o Mosteiro dos Jerónimos, que teve lugar por ordem do rei em Outubro de $1551^{62}$. Apenas uma certeza, que o próprio texto

${ }^{59}$ Ditos Portugueses Dignos de Memória. História Íntima do século XVI, edição anotada e comentada por José Hermano Saraiva, $3^{\mathrm{a}}$ edição, Lisboa, Europa-América, 1997, dito n. 1059, p. 380 .

${ }^{60}$ Maria José Azevedo Santos, «A escrita serve à mesa...». Agradecemos à Autora a oferta deste seu trabalho, dando a conhecer uma fonte preciosa para o conhecimento dos produtos alimentares consumidos na corte portuguesa de Quinhentos.

${ }^{61}$ Manteiga em medidas. Agradecemos este e outros esclarecimentos ao nosso colega João Silva de Sousa.

${ }^{62}$ Ana Isabel Buescu, «Uma sepultura para o rei. Morte e memória na trasladação de D. Manuel (1551)», in Lugares de Poder, coord. de Gérard Sabatier e Rita Costa Gomes, Lisboa, Fundação Calouste Gulbenkian/Acarte, 1998, p. 184-203. 
assinala com abundância: tudo se passou em Maio, no tempo das cerejas... E um comentário: a presença reiterada da manteiga, lado a lado com o azeite, gordura da tradição alimentar mediterrânea, testemunhando como a silenciosa «invasão» dos territórios gastronómicos do Sul da Europa pela «bárbara» manteiga e a sua incorporação na cozinha meridional no final da Idade Média era já, também na cozinha dos reis, apesar de algumas resistências, uma realidade indiscutível ${ }^{63}$.

Embora parcos, há ainda alguns testemunhos dispersos aos gostos, predilecções e até excessos alimentares do próprio monarca. D. João III comia bem, e com apetite -era mesmo, de acordo com testemunho anónimo coevo, «desenfreado com as mesas» e as digestões ressentiam-se ${ }^{64}$. Em 1557, pouco antes de morrer, já muito debilitado, o monarca comia em excesso, na opinião do embaixador castelhano Sancho de Córdoba, como referia em carta enviada à princesa D. Joana de Portugal $^{65}$, não dispensando quatro refeições diárias; à merenda, o menos que ingeria era queijo fresco e frutas, evidenciando uma predilecção especial por bebidas e águas «enfriadas» ${ }^{66}$. Era capaz de comer «quatro frangãos e uma torta bem adubada de carne e por cima natas frescas aparadas do coalho do leite, tudo com mui doce melaço ${ }^{67}$.

Apesar destes excessos de mesa de D. João III, tradicionalmente as principais refeições do dia eram o jantar, tomado pelo meio-dia e a ceia, a refeição da noite, no que afinal a corte não diferia de uma prática geralmente observada em todas as classes sociais. As parcas referências a uma terceira refeição, o almoço, parecem indiciar tratar-se de uma refeição de carácter secundário, não necessariamente associada a uma determinada hora do $\operatorname{dia}^{68}$, embora por vezes seja claro que se refere ao actual «pequeno almoço», ou

${ }^{63}$ Jean-Louis Flandrin, «Le goût et la nécessité...», pp. 369-401; «Et le beurre conquit la France», La Cuisine et la Table ..., pp. 108-112; Massimo Montanari, «Condimento, fondamento. Le matiere grasse nella tradizione alimentare europea», in Alimentazione e Nutrizione..., pp. 2751. Jean-Jacques Hémardinquer, «Les graisses de cuisine en France. Essais de cartes», Cahiers des Annales, 28, Pour une Histoire de l'Alimentation..., pp. 254-271. O «triunfo» da gordura animal nas cozinhas europeias é anterior, podendo fazer-se remontar aos primeiros séculos medievais. Montanari, ob. cit., p. 47.

${ }^{64}$ BNP, cod. 10761, fl. 12.

${ }^{65}$ A princesa D. Joana (1535- 1573), filha do imperador Carlos V e de Isabel de Portugal, casou em 1552 com o príncipe D. João, filho de D. João III e de D. Catarina, herdeiro do trono português. Depois da morte do príncipe e de ter dado à luz D. Sebastião, regressou a Castela em Maio de 1554, onde exerceu a regência na ausência de seu irmão Filipe, então rei consorte em Inglaterra. Nunca mais voltou a Portugal.

${ }^{66}$ Carta de Sancho de Córdoba à princesa D. Joana, de 14 de Junho de 1557, cit. por Alfonso Danvila y Burguero, Don Cristobal de Moura, Primer Marqués de Castel Rodrigo (1538-1613), Madrid, Real Academia de la Historia, 1900, p. 63.

${ }^{67} \mathrm{BNP}$, cod. 10761, fol. $72 \mathrm{v}$.

${ }^{68}$ Salvador Dias Arnaut, A Arte de Comer..., pp. 55-60. Bruno Laurioux, ob. cit., pp. 87-88. 
«primeiro-almoço», como também é designado. Esta centralidade, no quotidiano alimentar, de duas refeições principais é mais clara ainda na língua castelhana -além da «comida» e da «cena», o «desayuno», primeira e leve refeição do dia, tomada pela manhã, tinha como finalidade, literalmente, «cortar o jejum», o que diz bem da escassa importância que lhe era atribuída. Havia ainda a «merenda», ocasional e, em princípio, leve refeição da tarde, mais frequente, como podemos compreender, nos meios mais abastados- crónicas e outras fontes referem, com alguma frequência, as merendas de reis e rainhas, ocasião sobretudo associada a momentos de ócio ou de lazer, a visitas realizadas e a recebimentos, mas também ao despacho: é conhecida a visual descrição que Damião de Góis faz das merendas de D. Manuel que, estando em Lisboa, de quando em vez dava o seu passeio de barco, acompanhado de músicos, fidalgos e «algum oficial seu com que ia despachando»; a meio da tarde aportava ao cais de Santos o Velho onde Duarte Foreiro, cavaleiro da sua casa, «lhe mandava trazer de merendar de muitas fruitas verdes, conservas, \& cousas de açúcar, vinho, \& água [...]» ${ }^{69}$.

Jantar e ceia eram normalmente constituídas por carne e peixe, bebidas -água ou vinho- e sobremesas -fruta, fresca seca ou em conserva, e doces. O que diferia, sim, e o que singularizava a mesa do rei de todas as outras era a ostentação da abundância, efeito simbólico de tanto relevo numa sociedade de tantas e múltiplas carências, que permanentemente oscilava entre a abundância e a miséria $^{70}$. Na Idade Média, como observa Massimo Montanari, um difuso sentimento de insegurança e de medo perante a carência alimentar favorecia atitudes e, até, reacções por vezes violentas e incontroláveis perante a comida: «chi poteva, mangiava molto, in modo quasi rapace: lo stile di alimentazione di gran parte dell'aristocrazia era improntato a questo modello; per essa, mangiare molto era un vero status-symbol» ${ }^{71}$. Mas esse sentimento proporcionava, também, a abertura à utopia: a partir do século XIII, embora lançando raízes muito mais longínquas, e em articulação com outros momentos de inversão, como o Carnaval, os «países de Cocagne» da «cultura popular» transmitiam a concepção utópica de um milénio igualitário em que o motivo central era o do «paraíso alimentar»: no cenário de uma geografia imaginária, suspensa no tempo, todos, homens e mulheres, jovens e velhos, comiam e bebiam em abundância e sem esforço, num momento de dádiva feliz de uma natureza pródiga e mágica -verdadeiramente, um «mundo ao contrário» ${ }^{72}$.

${ }^{69}$ Damião de Góis, Crónica do Felicíssimo..., P. IV, cap. 84, p. 225.

${ }^{70}$ Iria Gonçalves, «Entre a abundância e a miséria...».

${ }^{71}$ Massimo Montanari, Alimentazione e cultura..., p. 91.

${ }^{72}$ François Delpech, «Aspects des Pays de Cocagne. Programme pour une recherche », L'Image du Monde Renversé et ses Représentations Littéraires et Para-Littéraires de la fin du XVIe siècle au Milieu du XVIIe Siècle, Études réunies et présentées par Jean Lafond et Augustin Redondo (Actes du Colloque International de Tours, 17-19 Novembre 1077), Paris, Vrin, 1979, pp. $35-48$. 
Assim, nesta sociedade frágil, em que o espectro da fome permanentemente assomava, a mesa do rei devia ser farta, porque através dessa fartura, mas também através da sua encenação e ritualização se evidenciava o seu poder. Por isso muitas vezes os monarcas viam suceder-se à mesa uma quantidade extraordinária de pratos nos seus jantares e ceias, muitos dos quais regressavam, sem ser tocados, às cozinhas -mais do que o acto de comer, o poder do rei mostrava-se no cerimonial que rodeava a refeição, neste sentido tornada um verdadeiro acto ritual ${ }^{73}$. Também as refeições ligadas a ocasiões cerimoniais importantes ou datas centrais do calendário litúrgico, como o dia que assinalava o nascimento de Cristo, eram ocasiões privilegiadas para o monarca acentuar e marcar o seu «poder distributivo». Damião de Góis nota como D. Manuel fazia questão de transformar a ceia de Natal, terminada a pública, solitária e cerimonial refeição régia, numa geral celebração, em que o soberano, num ambiente festivo, dava de consoar a toda a corte, grandes e pequenos, o que sobrava daquele «banquete, que todo era de frutas verdes, \& de açúcar, \& de conservas que the traziam da ilha da Madeira» ${ }^{74}$.

Mas era perante esta mesma mesa farta e abundante que o rei, como advertiam teólogos e moralistas desde a época medieval, devia cultivar a temperança, virtude tantas vezes ausente dos meios cortesãos. Na verdade, a gula, pecado capital, era considerada com frequência um vício próprio da corte -e, talvez, afinal, de forma não totalmente infundada: pois não eram a fartura e os correlatos excessos alimentares tantas vezes um sinal de distinção social, um verdadeiro status-symbol aristocrático, para retomarmos os termos de Montanari? ${ }^{75}$ Não por acaso, duas das obras centrais do discurso anti-áulico nos séculos XV e XVI, a celebrada De Curialium Miseriis Epistola de Aeneas Silvio Piccolomini (1473) e o não menos conhecido Menosprecio de Corte y Alabanza de Aldea de Antonio de Guevara (1539), dão um lugar de singular relevo aos excessos alimentares da corte, fazendo perfilar a gula como um vício próprio de um quotidiano cortesão recheado de lugares sombrios e práticas funestas ${ }^{76}$. Num

${ }^{73}$ Carmelo Lisón Tolosana, La Imagen del Rey..., p. 130. Sobre os mecanismos de conservação e transmissão da memória social, na sua articulação com as cerimónias comemorativas e práticas corporais, em que as «performances» e os momentos rituais têm um lugar central, ver o sempre estimulante estudo de Paul Connerton, Como as Sociedades Recordam (1 ${ }^{\mathrm{a}}$ ed. inglesa 1989), Oeiras, Celta Editora, 1993.

${ }^{74}$ Damião de Góis, ibidem. Ver a descrição da primeira ceia de Natal de D. Manuel depois de casado com a infanta D. Maria, filha dos Reis Católicos, pela pena do embaixador castelhano Ochoa de Isasaga, datada de 25 de Dezembro de 1500, que confirma esta dimensão da refeição natalícia do rei transmitida por Damião de Góis, in Documentos Referentes a las Relaciones com Portugal durante el Reinado de los Reyes Católicos, ed. preparada y anotada por António de la Torre y Luís Suarez Fernandez, vol. III, Valladolid, 1963, doc. 497, pp. 77-85.

${ }^{75}$ Massimo Montanari, Alimentazione e cultura..., p. 91.

${ }^{76}$ De Curialium Miseriis Epistola, cap. «De los sentidos del gustar: y oler», ed. cit.: Tractado de la Miseria de los Cortesanos, que escrivio el Papa Pio, ante que fuesse Summo Pon- 
outro plano, e significativamente, a gula era ainda com frequência associada, talvez mais do que qualquer outro excesso, à luxúria e ao pecado da sensualidade, como sucedia de forma absolutamente clara na Summa Theologica de S. Tomás de Aquino ${ }^{77}$, realidade que desde a Idade Média a Igreja, através de uma abundante literatura de carácter moralizante, se esforçava por denunciar ${ }^{78}$; em suma, o que estava em causa era a velha relação entre sexo e comida, o que nos permite compreender melhor os vários sentidos possíveis da invocação dos «méritos da fome» e da frugalidade da tradição monástica ${ }^{79}$.

Aliás, a literatura normativa relativa à formação do príncipe, ainda no século XVI, no âmbito do itinerário pedagógico que os mestres deviam incutir aos seus pupilos, concedia particular destaque ao controlo das paixões e à temperança, devendo o príncipe aprender a evitar todos os excessos, nomeadamente na comida ${ }^{80}$. Se tomarmos como exemplo o Libro Primero del Espejo del Principe Christiano (1544), da autoria de Francisco de Monçon, capelão e pregador de D. João III, obra destinada à educação do príncipe herdeiro, D. João (n. 1537), e que constitui a obra pedagógica de feição aristocrática de maior envergadura publicada em Portugal no século $\mathrm{XVI}^{81}$, facilmente constatamos a particular atenção conferida a esta virtude, e a

tífice, a un cavallero amigo suyo Coimbra, João de Barreira, 1563; Antonio de Guevara, Menosprecio de Corte y Alabanza de Aldea (1539), cap.XVI, ed. de Asunción Rallo Gruss, Madrid, Ediciones Cátedra, 1984, pp. 241-250. A crítica aos banquetes e seus excessos e os condicionamentos - servidão, competição, falta de liberdade - e códigos da «comida cortesã» e, na generalidade, a preocupação pela comida são aspectos recorrentes não só no Menosprecio... ou no Aviso de Privados y Doctrina de cortesanos (1539) (cap. VII, cap. XVIII) como no conjunto da obra guevariana. Ver Asunción Rallo Gruss, op .cit., p. 173, nota 6.

${ }^{77}$ Madeleine Pelner Cosman, Fabulous Feasts..., pp. 109-110, e ainda pp. 116-123, com sugestivo dossier iconográfico. No século XVI o meirinho Francisco do Casal afirmava gastar o dinheiro recebido das «mulheres solteiras» em vinho, justificando-se: «Como este dinheiro é de luxúria, não o gasto senão no melhor vinho, porque é o pai da luxúria, e eu de idade que já me não temo dela». Ditos Portugueses dignos de Memória... ed.cit., dito n. 493, p. 177. Esta articulação surge de forma ainda absolutamente explícita num texto de conselho e advertência sobre o ofício de rei, já do século XVII: Doze Lembrãças do Anonymo pera el Rey nosso sñor, provavelmente dedicado a Filipe III, BA, cod. 51-I-72, fol. 4-4v.

${ }^{78}$ Mireille Vincent-Cassy, «La gula curiale ou les débordements des banquets au début du règne de Charles VI», in La Sociabilité à Table..., pp. 91-102; Jacques Le Goff, «Saint Louis à table: entre commensalité royale et humilité alimentaire», in ibidem, pp. 133-144; Maria del Cármen Simon Palmer, «El cuidado del cuerpo de las personas reales: de los médicos a los cocineros en el real alcázar», in Le Corps dans la Société Espagnole..., pp. 113-122.

${ }^{79}$ Massimo Montanari, Alimentazione e cultura..., pp. 90-92.

${ }^{80}$ Ana Isabel Buescu, Imagens do Príncipe. Discurso Normativo e Representação (15251549), Lisboa, Cosmos, pp. 122-124.

${ }^{81}$ Francisco de Monçon, Libro Primero del Espejo del Principe Christiano, que trata como se ha de criar un Principe o niño generosos des de su tierna niñez cõ todos los Exercicios \& virtudes que le convienen hasta ser varon perfecto. Contiene muy singulares doctrinas morales y apazibles, Lisboa, Luís Rodrigues, 1544 (BNP, F. 4358). 
importância da configuração de um discurso regulador e de advertência em torno da mesa do príncipe. O Libro Primero... preceituava que o príncipe não devia comer antes do meio-dia, e não devia fazer mais de duas refeições (o que não se aplicava enquanto era criança, fase em que era conveniente comer várias vezes por dia). A sua mesa devia ser farta, mas dentro de limites que a sobriedade e a contenção impunham, e as «cenas» mais leves do que as «comidas» ${ }^{82}$. Era conveniente o príncipe sentar-se à mesa em posição elevada e a cerimónia do comer, acto «físico» por excelência, deveria ser acompanhada por outro tipo de actividade, de tipo «espiritual», como a leitura de livros, talvez por oposição a uma corrente contrária aos pressupostos morais aqui evidenciados, que defendia a presença do riso nas refeições dos reis ${ }^{83}$. Esta prática era de resto frequente, na época, através da presença dos bobos no momento das refeições, tanto nas casas nobres como nos palácios dos reis ${ }^{84}$. O número de pessoas à sua mesa devia ser pequeno, e o príncipe e demais convivas deviam observar honestidade na postura $^{85}$. Era dado, naturalmente, um lugar de relevo ao vinho, sendo-lhe dedicados três capítulos onde se enunciavam os danos, físicos e morais, decorrentes do seu consumo excessivo, as suas propriedades, e se estabelecia um minucioso elenco das regras que o príncipe deveria observar se bebesse vinho ${ }^{86}$.

Mas a alimentação regrada não respeitava apenas à aquisição da virtude da temperança e ao controlo de pulsões, mas também, e de forma central, ao corpo físico e à manutenção da saúde do príncipe. Esta dimensão era objecto de um capítulo em que, também com extremo pormenor, se estabeleciam as regras a observar na alimentação do príncipe para conservação da sua saúde: estando doente, era necessário procurar que a doença não se generalizasse, através de uma alimentação adequada; o príncipe deveria acostumar-se a comer de tudo, a comer pouco e pouca variedade de cada vez; nunca devia beber em jejum, procurando ter-se cuidados particulares com a fruta e o vinho; era necessário observar com rigor a ordem dos manjares, assim como a periodicidade das refeições, de acordo com a sua idade; tornando-se conveniente comer menos quantidade ao jantar, e não fazer qualquer exercício depois da refeição ${ }^{87}$. Em

${ }^{82} \mathrm{~A}$ «comida», tomada pelo meio-dia, era a refeição principal, correspondendo ao «jantar» que surge nas fontes portuguesas; e a «cena» a refeição da noite, a «ceia» em português.

${ }^{83}$ Fernando Bouza Alvarez, Locos, enanos e hombres de placer en la corte de los Austrias. Oficio de burlas, Madrid, Ed. Temas de Hoy, 1991, pp. 88-92.

${ }^{84}$ Ibidem; María del Carmen Simón Palmer, «El cuidado del cuerpo de las personas reales: de los médicos a los cocineros en el real alcázar», in Le corps dans la société espagnole..., p. 115.

${ }^{85}$ Francisco de Monçon, Libro Primero..., cap. XXXVI, fols. 108-112.

${ }^{86}$ Libro Primero..., cap.XXXVII a XXXIX, fols. 112-122v.

${ }^{87}$ Francisco de Monçon, Libro Primero..., cap. XXIV, fols. 66v-70 que, apesar do título apresentado, «del cuydado que en la vida ordinaria y en los pasatiêpos y recreaciones se ha de tener dela salud del principe», acaba por incidir quase exclusivamente na questão da alimentação, e nas nove regras para manter a saúde do príncipe. 
suma, o tratado de Francisco de Monçon, em pleno século XVI, evidenciava, de forma extremamente minuciosa, como a alimentação do príncipe, longe de apenas dizer respeito à satisfação de uma necessidade elementar e quotidiana, constituía um motivo central da sua educação, articulando uma dimensão moral, política e sanitária, em que a advertência contra excessos e interditos tinha um importante lugar.

Neste discurso regulador e de advertência contra o desregramento alimentar na corte em causa estava, e sempre com grande relevo, como sucede no tratado de Monçon, o consumo de vinho; vinho que na sociedade cristã ostentava uma dupla condição simbólica: a de «vinho místico», eucarístico, o sangue de Cristo oferecido aos fiéis pela transubstanciação, mas também a de bebida desreguladora ou mesmo «diabólica», tal como tão frequentemente surgia na iconografia medieval ${ }^{88}$. Assim, ao vinho, no contexto da corte, associavam-se dois tipos de discursos, duas vozes dissonantes mas intimamente ligadas -a que fazia dele a bebida por excelência, tradicionalmente presente na mesa régia e consumida com largueza e abundância por reis e senhores ${ }^{89}$; e essa outra voz, que alertava para os perigos do seu consumo desregrado que o tornava, indiscutivelmente, o «emblema» maior da desregulação da temperança. Já o rei Afonso X de Castela, nas suas Siete Partidas, concedia uma atenção particular ao consumo de vinho pelo príncipe ${ }^{90}$; e o também medieval Segredo dos Segredos advertia contra os excessos do vinho, naquela que é, porventura, uma das mais expressivas e detalhadas diatribes contra o seu consumo excessivo: tomado em grandes quantidades, entre outras consequências, o vinho «obscurenta o entendimento, embarga o siso e torva o cérebro e enfraquenta a virtude natural e gera esquecimento [...]»; mas, de forma absolutamente original, recomendava-se também ao rei que, em ocasiões determinadas, mandasse beber os seus privados sem restrições, abstendo-se ele de o ingerir, «porque então poderás muitos segredos entender e ouvir [...]»-o vinho podia ser, também, um instrumento directo de poder do próprio rei ${ }^{91}$. Esta reiterada advertência contra o abuso do vinho não significava que, consumido com moderação, e diluído em água, como era aliás prática corrente e recomendada, o vinho não fosse objecto de louvores por parte dos próprios médicos ${ }^{92}$.

${ }^{88}$ Martine Vasselin, «Des fastes de Bacchus aux beuveries flamandes : l'iconographie du vin de la fin du XVe siècle à la fin du XVIIe siècle », Nouvelle Revue du XVIe Siècle, n. 17/2, 1999, pp. 219-251.

${ }^{89}$ Iria Gonçalves, «À Mesa, com o Rei de Portugal...», p. 18 e nota 10.

${ }^{90}$ VER as considerações relativas ao seu consumo pelo príncipe nas Partidas de Afonso X, o Sábio (Rei de Castela), Las Siete Partidas del Rey Don Alfonso El Sabio, cotejadas con varios codices antiguos por la Real Academia de la Historia, 3 Tomos, Madrid, Imprenta Real, 1807, Partida II, tít. V, lei II, pp. 25-26 e tít. VII, lei VI, pp. 48-49.

${ }^{91}$ Pseudo-Aristóteles, Segredo dos Segredos..., p. 42 e p. 17, respectivamente.

${ }^{92}$ Jeanne Allard, ob. cit., pp. 97. 
A noção que fica, no seu conjunto, é a de que a corte não era vista como um espaço de sobriedade ou de frugalidade alimentar, mas um lugar onde a fartura permitia e proporcionava o excesso que facilmente podia originar a enfermidade ou o vício, justificando, afinal, o olhar crítico que moralistas, teólogos ou médicos lançavam sobre a alimentação de reis, príncipes e grandes senhores. Médicos e físicos faziam aliás radicar nos excessos de mesa um conjunto de doenças que Lobera de Ávila, médico de Carlos V e autor daquele que é considerado o primeiro tratado de dietética da Época Moderna, o Vanquete de Nobles Cavalleros, publicado pela primeira vez em 1530, classificava de modo significativo, num outro texto de sua autoria, como «enfermedades cortesanas ${ }^{93}$. Os tratados do médico de Carlos V consistiam, fundamentalmente, num discurso de advertência e de «regulação alimentar» destinado ao imperador e aos nobres que, pela sua condição social, eram os principais protagonistas da dimensão sombria, a um tempo moral e sanitária, da fartura alimentar. Discurso que evidenciava a absoluta preeminência de uma medicina centrada na teoria dos humores, com consequências directas no tipo de alimentação adequada a cada indivíduo, de forma a manter ou a recuperar a saúde ${ }^{94}$. A 30 de Julho de 1544, estando D. João III em Évora, o físico António Maldonado escrevia ao secretário Pero de Alcáçova Carneiro, aconselhando que se o rei tivesse «algum encendimento de cólera», deveria alimentar-se de «ceias leves e mantimentos frios como frangãos», e abster-se de «muito exercício» e de montar muitas vezes a cavalo; estas advertências tornavam-se mais incisivas quanto aos cuidados a ter com a alimentação do frágil $\mathrm{D}$. João, herdeiro do trono: os «mantimentos e a vianda» do príncipe deviam ser leves, de modo a que «no se encienda la colera e altere o sangre [sic] $\gg^{95}$.

Voltando à mesa do rei, é seguro afirmar que o rei de Portugal comia normalmente sozinho, rodeado dos seus oficiais e fidalgos, que o assistiam, embora nem sempre tal sucedesse. É célebre a pormenorizada descrição que o sempre atento Garcia de Resende faz dos banquetes na «sala de madeira», por ocasião do casamento do príncipe D. Afonso, filho de D. João II e herdeiro do trono, com D. Isabel, filha primogénita dos Reis Católicos, em 1490. Nesse solene e festivo momento, à mesa com o rei comeram também a rainha $\mathrm{D}$. Leonor, o príncipe e a princesa, D. Manuel, duque de Beja, D. Jorge, filho bastardo do monarca português e o embaixador castelhano ${ }^{96}$.

${ }^{93}$ Libro de las Quatro Enfermedades Cortesanas..., publicado em 1544. Ib., p. 100.

${ }^{94}$ Ver supra, nota 29.

${ }^{95}$ IAN//TT, CC, Parte I, mç.75, n. 43.

${ }^{96}$ Garcia de Resende, Crónica de D.João II, cap. CXXIV e CCXXV, in Crónica de D. João II e Miscelânea por Garcia de Resende, nova edição conforme a de 1798, com Introdução de Joaquim Veríssimo Serrão, Lisboa, IN-CM, 1991, pp. 173-176. 
Em suma, quer em ocasiões assinaladas quer em momentos sem especial significado cerimonial, no quotidiano da corte, o rei comia muitas vezes só à mesa. Dois documentos excepcionais permitem-nos ter uma noção mais nítida desta questão. Em carta enviada aos Reis Católicos, datada de 24 de Novembro de 1500, dando notícias da jovem e recém-casada rainha de Portugal, D. Maria, mulher de D. Manuel, o embaixador Ochoa de Isasaga descrevia pormenores do quotidiano da corte portuguesa, aludindo, por duas vezes, ao momento das refeições régias. Através dele sabemos que nesse domingo o rei e a rainha ouviram missa juntos, «y comieron cada un por su parte, com tronpetas $e$ menestriles»; e na $2^{\mathrm{a}}$ feira, de tarde, D. Manuel e D. Maria deslocaram-se a ver as obras do grande hospita ${ }^{97}$ que então se construía em Lisboa, ocasião em que o povo da cidade mostrou «mucho plazer en ver a la señora reyna, echandole muchas vendiçiones [sic]». No regresso ao palácio, depois de permanecerem juntos até ao anoitecer, o rei despediu-se da rainha para cear, e «la señora reyna çeno retrayda» ${ }^{98}$. Cerca de um mês depois, as festas de Natal dos monarcas portugueses ilustram, de forma exemplar, o que queremos sublinhar: no dia 24, depois de ouvirem juntos as vésperas na capela real, D. Manuel conduziu D. Maria aos seus aposentos, dirigindo-se em seguida à sala grande do palácio onde, num grande estrado com dossel de brocado, se encontrava uma grande e rica cadeira e uma mesa em frente; sentando-se o rei, rodeado pelos seus oficiais e fidalgos, aí lhe foi servida «com gran triunfo», a ceia de Natal, que depois D. Manuel distribuiu por todos os presentes. Ao mesmo tempo, a rainha comia na sua câmara, ceando depois as suas damas. $\mathrm{O}$ almoço do dia seguinte, em que à sua mesa o rei teve peixe, fez-se também em separado; mas à noite, terminadas todas as cerimónias e findas as extraordinárias festas do dia de Natal que envolveram toda a corte, por volta da meia-noite e meia, D. Manuel e D. Maria recolheram-se à sua câmara, onde «cenaron juntos muy alegremente», deitandose em seguida ${ }^{99}$.

Era sobretudo em ocasiões cerimoniais importantes que o rei podia, se assim o determinasse, conferir a distinção de partilhar a sua mesa, como aconteceu, em Novembro de 1525, nos desposórios da irmã de D. João III, a infanta D. Isabel, com o imperador Carlos V, ocasião em que os infantes e os embaixadores do imperador partilharam também a mesa de D. João III. Nesse dia

\footnotetext{
${ }^{97}$ O Hospital de Todos-os-Santos.

${ }^{98}$ Carta de Osoa de Isasaga aos Reis Católicos, publicada in Documentos Referentes a las Relaciones..., vol. III, doc. 494, pp. 66-69.

${ }^{99}$ Carta de Osoa de Isasaga aos Reis Católicos, de 25 de Dezembro de 1500, publicada in Documentos Referentes a las Relaciones..., vol. III, doc. 497, pp. 77-85. Trata-se de um documento excepcional a vários títulos, com destaque para a descrição pormenorizada das festas de Natal na corte manuelina que, longe de revestirem uma dimensão unicamente religiosa, mostravam bem, naquele declinar do mundo medieval, como o sagrado e o profano conviviam de forma que, irreversivelmente, iria desaparecer.
} 
2 de Novembro, dia seguinte às cerimónias do casamento, o rei, num acto considerado de subida e rara distinção em termos do habitual cerimonial da corte portuguesa, convidou ao jantar para a sua mesa os dois embaixadores que actuaram em nome de Carlos V, o senhor de La Chaux e Juan de Zúñiga, e os seus irmãos o cardeal D. Afonso e os infantes D. Luís e D. Fernando. A distribuição dos lugares não era aleatória: mais chegado ao rei encontrava-se o cardeal, depois o infante D. Luís e o infante D. Fernando. Depois deste, sentavam-se os embaixadores, um dos quais no topo da mesa. A comida dos embaixadores vinha cortada do aparador ou copa; a bebida, provavelmente vinho, foi-lhes servida pelos seus criados, não havendo na mesa mais oficiais do que os do rei e dos infantes. A descrição é muda sobre a presença quer da rainha D. Catarina quer da já imperatriz D. Isabel, depreendendo-se que, nesta ocasião, elas não estiveram à mesa do rei ${ }^{100}$.

Procedimento semelhante foi observado em 1543, quando no dia seguinte aos desposórios da infanta D. Maria com Filipe de Castela no paço de Almeirim, o rei convidou o embaixador Luis Sarmiento para a sua mesa, mas não, como se refere expressamente, o núncio papal ${ }^{101}$. Em 1565, num dos banquetes realizados no paço da Ribeira por ocasião do casamento de D. Maria com Alexandre Farnese, à mesa de D. Sebastião encontravam-se apenas D. Duarte, Condestável do reino e irmão de D. Maria ${ }^{102}$, e o embaixador castelhano, Alonso de Tovar, procurador do noivo; a rainha D. Catarina, a noiva, e a infanta D. Maria, irmã de D. João III, servidas pelas suas damas, comeram nos aposentos da rainha, cujo umbral não foi transposto por quem servia as iguarias, observando-se uma rigorosa separação de sexos que não deixou de surpreender os membros da comitiva do noivo; só após o banquete, o rei e a rainha, príncipes e embaixadores, damas e nobres se reuniram num mesmo espaço, dando-se então início a um serão em que, depois da tradicional cerimónia do beija-mão real, a dança teve, enfim, o protagonismo principal ${ }^{103}$.

Alguns anos mais tarde, em Dezembro de 1571, D. Sebastião recebeu em Lisboa o núncio do papa Pio V, o cardeal Alexandrino, alojando-o nos velhos

${ }^{100}$ Relações de Pero de Alcáçova Carneiro, Conde da Idanha, do tempo que ele e seu pai, António Carneiro, serviram de secretários (1515 a 1568), publicação, revisão e notas por Ernesto de Campos de Andrada, Lisboa, Imprensa Nacional, 1937, pp. 232-233.

${ }^{101}$ Francisco de Andrada, Crónica de D. João III, Introdução e Revisão de Manuel Lopes de Almeida, P. III, cap. 88, Porto, Lello \& Irmão, 1976.

102 D. Duarte (1541-1576), figura hoje bastante esquecida, que chegou a estar na segunda linha da sucessão do trono português, imediatamente após seu primo o rei D. Sebastião. Filho (póstumo) do infante D. Duarte († 1540), irmão de D. João III, e de D. Isabel (†1576), irmã de D. Teodósio, $5^{\circ}$ duque de Bragança.

${ }^{103}$ Giuseppe Bertini, «The Marriage of Alessandro Farnese and D. Maria de Portugal in 1565: Court Life in Lisbon and Parma», in Cultural Links Between Portugal and Italy in the Renaissance, edited by K. J. P. Lowe, Oxford, Oxford University Press, 2000 , p. 56. 
paços da Alcáçova -que o jovem monarca preferia ao da Ribeira nas breves estadias que fazia em Lisboa- «todos muito bem ornados, com toda a tapeçaria rica que o rei tinha, e alguma da infanta D. Maria» ${ }^{104}$. O cardeal ficou instalado em aposentos luxuosamente preparados no andar de cima dos de D. Sebastião, e jantou com os bispos e nobres numa parte da «sala do dossel», e os gentishomens da sua numerosa comitiva na outra parte do aposento, uma refeição abundantemente servida de delicados manjares; ao mesmo tempo, D. Sebastião comia, só, «na sua sala principal, debaixo do dossel, em estrado levantado, $e$ assentado em cadeira de brocado de ouro» ${ }^{105}$.

Quando não comia sozinho, o número de pessoas que se sentavam à mesa do rei de Portugal era portanto, e de uma forma geral, restrito. A solidão do monarca à mesa, enfatizando a majestade e a singularidade do seu estado, era aliás observada na corte papal, que constituía muito provavelmente, neste particular, segundo Bertelli, o modelo das cortes medievais europeias ${ }^{106}$. Le Goff sustenta, no entanto, que na época medieval com excepção da corte papal e, mais tarde, das monarquias absolutas, eram mais numerosos os casos em que, com um número maior ou menor de convivas, os reis comiam acompanhados ${ }^{107}$, numa apreciação que, com frequência, as fontes parecem desmentir ${ }^{108}$; mas talvez não se possa generalizar. Em qualquer dos casos, é certo que o acto de comer, acto físico por excelência, pela dimensão ritual que tinha no caso da realeza, revestia um significado simbólico profundo, no caso do rei, como já sublinhámos, litúrgico e até sacral ${ }^{109}$.

O manual litúrgico que pertenceu à princesa $\mathrm{D}$. Maria de Portugal, princesa de Parma, descoberto em Nápoles e recentemente publicado ${ }^{110}$, é um importantíssimo e inédito testemunho das cerimónias da capela real no reinado de D. João III, numa época em que em Portugal não existia ainda um Regimento sistematizando os ritos e cerimónias aí observados, pela primeira vez instituído

${ }^{104}$ BNP, cod. 8570, com uma relação interessante e pormenorizada relação do recebimento do cardeal no reino, fols. $146-147 \mathrm{v}$.

${ }^{105}$ Relato do secretário Giovanni Battista Venturino, que acompanhava o núncio, publicado por Alexandre Herculano, «Viagem do cardeal Alexandrino», in Opúsculos, T. VI, Controvérsias e Estudos Históricos (Tomo III), $5^{\text {a }}$ edição, Lisboa, Livraria Bertrand, s/d, pp. 84-85.

${ }^{106}$ Sergio Bertelli, ob. cit., pp. 164-170.

${ }^{107}$ Jacques Le Goff, «Saint Louis a table: entre commensalité royale et humilité alimentaire», in La Sociabilité à table..., p. 133.

${ }^{108}$ No seu Boke of Nurture (c. 1460), John Russell enumerava cinco classes sociais, e o lugar preciso de cada uma à mesa, afirmando, para os que pertencem ao vértice da pirâmide social: «[...] pope, emperor, king, cardinal, prince, archbishop, and duke, were of such dignity as to dine alone». Cit. por Madeleine Pelner Cosman, Fabulous Feasts..., p.107.

${ }^{109}$ Sergio Bertelli, Il Corpo del Re..., pp. 164-185.

110 José Maria Pedrosa Cardoso, Cerimonial da Capela Real. Um manual litúrgico de D. Maria de Portugal (1538-1577) Princesa de Parma, Lisboa, Imprensa Nacional-Casa da Moeda/Fundação Calouste Gulbenkian, 2008. 
por Filipe II, em $1592^{111}$. Nele está bem patente, entre muitos outros, com destaque para a música da capela, este aspecto que queremos aqui relevar: a bênção da mesa do rei, precedendo a refeição, nas várias situações que se apresentavam -em dia de missa pontifical ou de missa ordinária, quando o rei comia acompanhado da rainha, em dia de jejum e peixe- reflectia, indiscutivelmente, essa dimensão sacral que envolvia a mesa do monarca, acto que, porventura como poucos outros de entre os cerimoniais régios, se situava nesse espaço que unia o sagrado e o profano, religando, através da palavra e do gesto do oficiante, o poder da monarquia ao poder do divino ${ }^{112}$. E não era a mesa do rei -nem que fosse subliminarmente- também uma mensa domini, como o altar do Senhor?

Num outro plano, o cerimonial que rodeava o rei à mesa reflectia também a importância da hierarquia da mesa, considerada desde a Idade Média como um dos mais relevantes da vida na corte, sujeito a uma regulação ritual e a códigos cada vez mais precisos -embora tal processo fosse, naturalmente, um processo de lenta inculcação. Para meio do século XVI, no caso de uma Espanha politicamente unificada sob o ceptro da austríaca dinastia Habsburgo, revestir-seia de significado decisivo a introdução em 1548 na casa do herdeiro do trono, Filipe das Astúrias, por ordem de seu pai o imperador Carlos V, do ritual da requintada corte da Borgonha que, constituindo no seu conjunto uma evolução no sentido de uma sistematização mais complexa dos cerimoniais e da «teatralização» da corte, dava um particular relevo ao conjunto de cerimónias que rodeava a mesa do soberano ${ }^{113}$. Por outro lado, na perspectiva mais geral de uma «civilização dos costumes», a mesa constituía, nas épocas medieval e moderna, como o sociólogo Norbert Elias observou de forma pioneira, um dos «espelhos» privilegiados da civilidade e da aquisição das boas maneiras, como se torna evidente com o destaque que gestos e comportamentos a observar no momento das refeições assumiam no conjunto da literatura de civilidade ${ }^{114}$. No

${ }^{111}$ Ibidem, p. 17.

${ }^{112} \mathrm{Ib}$., pp. 124-126.

113 Carmelo Lisón Tolosana, ob. cit., pp. 115-131; Werner Paravicini, «The Court of the Dukes of Burgundy: a Model for Europe?», in Princes, Patronage and the Nobility. The Court at the Beginning of the Modern Age, c. 1450-1650, ed. Ronald Ash e Adolf Birke, Oxford, Oxford University Press, 1991, pp. 99-102; Jeanne Allard, «Les grands banquets à la cour de Charles Quint», in La Sociabilité à table ..., pp. 145-153, e María del Carmen Simon, «La théatralité des repas royaux dans l'Espagne des XVI et XVII siècles», ibidem, pp. 159-168; Bruno Laurioux, op. cit., pp. 98-100; Marzio A. Romani, «Regalis coena...».

${ }^{114}$ Norbert Elias, La Civilisation des Moeurs, Paris, Calman Lévy, 1973 (1ª ed. alemã 1939), pp. 88 e ss. e pp. 121-183; Philippe Ariès, L'enfant el la vie familiale sous l'Ancien Régime, Paris, Seuil, 1973 (1 $1^{\text {a }}$ edição 1960), pp. 275-282; Daniela Romagnoli, «Cortesia nella città: un modello complesso. Note sull'etica medievale delle buone maniere», in La Città e la Corte. Buone e Cattive Maniere tra Medioevo ed Età Moderna, a cura di Daniela Romagnoli, con un saggio introduttivo di Jacques Le Goff, Milão, Ed. Angelo Guerini, 1991, pp. 47-48 e pp. 59-61 (tradução 
âmbito da casa real, esta realidade implicava, nos bastidores, uma organização cada vez mais complexa, dos cargos, funcionários e criadagem que asseguravam os serviços ligados à mesa, à cozinha e à ucharia régias -copeiros, trinchantes, cozinheiros, pasteleiros, confeiteiros, para não falar dos moços de cozinha e outros ofícios menores ${ }^{115}$. Nos aposentos em que tinham lugar as refeições, eram as artes de mesa, através da presença e do uso de objectos de grande riqueza e aparato $^{116}$, o ritmo processional da apresentação dos manjares, a ritualização precisa dos gestos de todos os protagonistas, que mostravam o fausto da refeição do rei.

Mas a própria comida, desde a sua apresentação, que revestia, com frequência, aspectos de verdadeira «arte efémera», sobretudo em banquetes cerimoniais, de que existem impressionantes descrições, até à água consumida à mesa, podia ser sinal e instrumento da encenação do poder do rei e da monarquia. Num dos banquetes oferecidos pela rainha D. Catarina aos nobres enviados por Margarida de Parma a Lisboa, por ocasião do casamento de sua sobrinha D. Maria com Alexandre Farnese, a que já aludimos, ao som de suave música e vozes cristalinas que acompanharam o desenrolar do banquete, as abundantíssimas carnes que vieram à mesa vinham «miraculosamente» dos mais distantes pontos do império, e a água servida dizia-se proveniente de rios de muitas partes do mundo - do Indo ao Ganges, de nascentes e lagos de África e da Ásia, do próprio Tibre romano, simbolizando a imensidão das possessões e dos domínios imperiais do reino de Portugal...117.

Reconstituindo a refeição do rei ${ }^{118}$ : no aposento onde D. João III comia colocavam os reposteiros a mesa sobre uma alcatifa, no Inverno, ou uma esteira, no Verão; no caso de haver dossel no aposento, a mesa deveria colocar-se sob o mesmo. De acordo com uma prática antiga que remontava pelo menos ao rei D. Fernando ${ }^{119}$, o monarca devia comer em posição elevada, pelo que talvez existisse também um estrado, que é expressamente referido na descrição da mesa régia de D. Manuel no Natal de 1500, aquando dos desposórios da infanta D. Maria com Filipe das Astúrias, em 1543, ou, mais tarde, na descrição de 1571 de

francesa, com alterações, La Ville et la Cour. Des bonnes et des mauvaises manières Paris, Fayard, 1995); Claudine Marenco, Manières de Table, Modeles de Moeurs, 17e-20e siècle, Cachan, Editions de l'ENS, 1992; Banquets et Manières de Table au Moyen Age, Actes du Colloque du Centre Universitaire d'Etudes et de Recherches Médiévales d'Aix, Aix-en-Provence, 1996.

${ }^{115}$ Para a época medieval, ver a síntese de Bruno Laurioux, op. cit., pp. 72-75.

116 Ver, para esta época, Maria do Carmo Rebelo de Andrade, «As Artes de Mesa e a ourivesaria de corte em Portugal na $1^{\mathrm{a}}$ metade do século XVI», in Encontro sobre as Transformações na Sociedade Portuguesa, 1480-1570, Lisboa, Fundação das Casas de Fronteira e Alorna, 1996, pp. 1-13.

${ }^{117}$ Giuseppe Bertini, ob. cit., p. 54 e 52.

${ }^{118}$ Seguimos de perto Maria José Azevedo Santos, Jantar e Cear..., pp. 50-54.

${ }^{119}$ A. H. de Oliveira Marques, A Sociedade Medieval Portuguesa..., p. 226 ; Salvador Dias Arnaut, A Arte de Comer..., 1986, p. 63. 
Venturino, como vimos. Chegava então o soberano com o capelão-mor, bispo em dia de missa pontifical ${ }^{120}$, acompanhado de outros dois capelães ${ }^{121}$, procedendose à cerimónia de bênção da mesa, onde já estavam dispostos o pão e o saleiro. $\mathrm{O}$ reposteiro-mor chegava-lhe a cadeira, e o lugar de todos os presentes, entre nobres e oficiais, era minuciosamente regulado -o vedor do lado direito do rei, os oficiais do serviço fora da alcatifa, o mestre sala do lado esquerdo, os moçosfidalgos de joelhos sobre a alcatifa, de um lado e do outro do soberano, acompanhando a refeição.

Depois, o trinchante dava o chamado prato de água às mãos ao rei, que as lavava e limpava a uma toalha de mãos estendida ao monarca pelo vedor. Seguia-se a entrada dos vários pratos, em padiolas, de onde D. João III escolhia o que queria comer, não sem que antes as iguarias tivessem sido provadas. Ao jantar, não sendo dia de jejum, a refeição apresentada ao monarca podia constar de «oito arráteis de carne, carneiro ou vaca, e uma galinha ou perdiz, e um arrátel da ros [sic] ${ }^{122}$ ou cuscus ou aletria e assim uma dúzia de ovos partidos pelo meio ${ }^{123}$ e um pedaço de marrão ${ }^{124}[. .]$.$» , de onde comia depois o capelão a$ quem coubera nesse dia a incumbência de benzer a mesa régia ${ }^{125}$.

O copeiro-mor servia de beber ao rei, provando a bebida antes do monarca -tal era também, como se sabe, uma tradição que se perdia na memória dos tempos, fundada no temor, sempre presente nos palácios de reis, imperadores, papas e grandes senhores, do envenenamento pela «peçonha». O episódio seguinte ilustra bem esta realidade. Estando um dia D. João III, pela hora da sesta, nas casas da rainha D. Catarina, pediu água; serviram-na de um barril que antes contivera vinagre rosado, que o pajem, Francisco de Sá de Meneses, provou da salva antes de o monarca beber; ao levar a água à boca o rei estranhoulhe o sabor, apressando-se o jovem pajem a bebê-la toda de um trago, perante a evidente perturbação do monarca, que por momentos acreditou que pudesse estar envenenada, exclamando: «Que me destes nesta água, que me matastes?»126.

A crermos nos testemunhos próximos de João de Barros, de António Luís ou do seu capelão Francisco de Monçon, D. João III não bebia vinho, apesar de este ser parte integrante das refeições de reis e de nobres, sendo o seu consumo

${ }^{120}$ Cerimonial da Capela Real..., ed. cit., pp. 124-125.

${ }^{121}$ Os domairos, «que serve[m], por semana, nos divinos ofícios». Fr. Joaquim de Santa Rosa de Viterbo, Elucidário das Palavras, Termos e Frases..., ed. crítica por Mário Fiúza, vol. II, Porto, Livraria Civilização, 1966, p. 201.

${ }^{122}$ É rara, para a época, a referência ao arroz, introduzido na Península Ibérica pelos Árabes, com a excepção do arroz com leite, ou seja, o arroz doce.

${ }^{123}$ Provável referência a ovos crus, na época uma das formas habituais em que eram consumidos, a par dos ovos fritos em azeite. Pedro Plasencia, op. cit., p. 115.

124 Porco.

${ }^{125}$ Cerimonial da Capela ..., ed. cit., p. 125.

${ }^{126}$ Ditos Portugueses..., dito n. 946. 
moderado recomendado, como vimos, pelos próprios médicos e dietistas ${ }^{127}$, e a sua presença na mesa régia sinal de fartura e poder -nos faustosos banquetes ocorridos na casa do embaixador Pedro de Mascarenhas, em Bruxelas, em 1531, para celebrar o nascimento do tão ansiado filho varão, o infante D. Manuel ${ }^{128}$, filho de D. João III e de D. Catarina, sucederam-se à mesa do imperador Carlos $\mathrm{V}$, convidado de honra do embaixador do rei português, além de delicados manjares de muitas carnes e aves, uma impressionante lista de vinhos, brancos e tintos, das mais variadas proveniências -o moscatel de Alcácer do Sal e um tinto claro da região de Lisboa, vinhos de Tarragona e das Baleares, uma grande variedade de delicados néctares de Itália, da Grécia e do Reno, na Alemanha ${ }^{129}$.

A refeição terminava com os doces trazidos pelo guarda-reposte numa confeiteira, que o rei mandava também repartir, como era tradição, pelos seus moços-fidalgos que se encontravam no aposento onde era servida a refeição; já Damião de Góis, a propósito da corte de D. Manuel, dava conta de que «a criação dos moços fidalgos do Rei de Portugal é estarem de joelhos à mesa, e darem-lhes os Reis fruta da que lhe trazem para comer ${ }^{130}$. Episódio que ilustra esta prática antiga do quotidiano da corte aconteceu um dia, estando Filipe Lobo, trinchante de D. João III, à mesa servindo o seu ofício quando trouxeram a cesta de fruta com maçãs para a sobremesa do rei; uma maçã rolou para o chão, precipitando-se os pequenos moços fidalgos para tentarem apanhá-la. Perguntando o monarca quem era o moço que acabara por conseguir a apetecida peça de fruta, retorquiu-lhe, não sem ironia, o seu trinchante: «Na sua fome não via Vossa Alteza que é meu filho?» ${ }^{131}$.

Terminava a refeição régia. $\mathrm{O}$ trinchante retirava, num prato a faca, a colher, o garfo e o guardanapo, bem como o pão que sobrava, levantavam-se as toalhas, o capelão dava graças a Deus e o monarca retirava-se acompanhado dos seus oficiais $^{132}$. E com a saída do rei, cai o pano sobre esta breve incursão nos domínios da mesa do rei de Portugal no século de Quinhentos.

${ }^{127}$ Salvador Dias Arnaut, op. cit., pp. 40-41; Ana Isabel Buescu, Imagens do Príncipe..., p. 123.

${ }^{128}$ Quinto filho de D. João III e de D. Catarina, nascido a 1 de Novembro de 1531, no Alvito, ardentemente desejado pois à data do seu nascimento só era viva sua irmã Maria (n. 1527), o infante D. Manuel chegou a ser jurado herdeiro do trono em Évora, em 1535; de constituição débil, veio a morrer antes de completar os seis anos de idade, a 14 de Abril de 1537, em Évora. Ana Isabel Buescu, D. João III (1502-1557), Lisboa, Temas \& Debates, 2008, pp. 197-202.

${ }^{129}$ André de Resende, Genethliacon, publicado em edição bilingue (latim e inglês) por John R. C. Martyn, On Court Life, Berna, Frankfurt, Nova Iorque, Paris, Peter Lang, 1990, pp. 81-83.

${ }^{130}$ Damião de Góis, Crónica do Felicísimo..., P. III, cap. 40.

${ }^{131}$ Ditos Portugueses..., dito n. 790.

${ }^{132}$ Maria José Azevedo Santos, Jantar e Cear..., p. 51. 